Volume 71

Issue 3 Texas Gulf Sulphur 50th Anniversary

Symposium Issue

Article 6

January 2018

\title{
Seeking an Objective for Regulating Insider Trading Through \\ Texas Gulf Sulphur
}

James D. Cox

Duke Law School

\section{Recommended Citation}

James D. Cox, Seeking an Objective for Regulating Insider Trading Through Texas Gulf Sulphur, 71 SMU L. REV. 697 (2018)

https://scholar.smu.edu/smulr/vol71/iss3/6

This Article is brought to you for free and open access by the Law Journals at SMU Scholar. It has been accepted for inclusion in SMU Law Review by an authorized administrator of SMU Scholar. For more information, please visit http://digitalrepository.smu.edu. 


\title{
SeEking AN OBJective For REgulating INSIDER TRADING Through Texas Gulf Sulphur
}

\author{
James D. Cox*
}

\begin{abstract}
Data summarized in the opening of this article document shows that inside trading is a growth industry. And, as deals get ever bigger, the growth curve becomes steeper as more the data confirms intuition that the more who know about a good thing the more who will seek to harvest its benefits. Even though insider trading appears to have thrived during the fifty years after Texas Gulf Sulphur, we gather in this symposium to celebrate the decision. But why? As developed below, the Second Circuit's landmark decision gave way to the Supreme Court's erection of a fiduciary framework that this article reasons is unhelpful. Little remains of Texas Gulf Sulphur. This article seeks to explain why the decision remains important. It counsels that insight to why and how to regulate insider trading lies in closely considering Texas Gulf Sulphur, whose rich facts but opaque reasoning in combination enable it to endure as a guidepost by which to locate at least two mutually supportive rationales, developed here, for regulating insider trading.
\end{abstract}

TABLE OF CONTENTS

I. FROM THE CLARITY OF PARITY OF INFORMATION TO THE MIST OF FIDUCIARY

DUTY .................................. 699

II. FINDING PURPOSE IN TGS'S FACTS ........... 706

A. Protecting the Reward for Initiative ......... 707

B. Necessary Prophylaxis Explanation ........... 708

III. THE PATH FORWARD $\ldots \ldots \ldots \ldots \ldots \ldots \ldots \ldots \ldots \ldots \ldots \ldots$

7 RADING on inside information is a growth industry. Studies repeatedly and consistently report that much of the price effect of financially significant corporate activity occurs before the particular event is publicly disclosed. ${ }^{1}$ Mergers and takeovers are particularly

* Brainerd Currie Professor of Law, Duke University. The author is grateful for the excellent research assistance of Mr. Brent M. Caldwell in preparing this article.

1. Initial studies of insider trading examined whether insiders (officers, directors, and certain beneficial owners) who are required to report their trading pursuant to $\S 16$ (a) of 
rife with insider trading abuses in the pre-announcement period. ${ }^{2}$ For example, one study found significant evidence of insider trading an average of twelve days prior to the first public announcement of a merger; about $40-50 \%$ of the price gain experienced by the targets of takeovers occurs before the actual takeover announcement. ${ }^{3}$ Because these transactions customarily involve significant market premiums to the acquired firm, and because their planning and execution involve a large number of individuals, each of whom faces the temptations of certain gains and uncertain detection if they trade on their secret knowledge, acquisitions are rife with evidence of insider trading. ${ }^{4}$ What is most revealing in recent studies is not that insider trading occurs on a massive scale in connection with many market-moving corporate events, but that the degree of such trading is proportional to the number of professionals engaged in marketmoving transactions. ${ }^{5}$ For example, a review of 1,859 merger deals from 1996 through 2012 found evidence of insider trading of options in $25 \%$ of all deals. ${ }^{6}$ Moreover, an increase in the number of insiders involved in deals appears to be driving this. ${ }^{7}$ For example, Professors Acharya and

the Securities Exchange Actabuse the informational advantage they enjoy by trading on nonpublic information. Jeffrey F. Jaffe, Special Information and Insider Trading, 47 J. Bus. 410, 413 (1974), and Joseph E. Finnerty, Insiders and Market Efficiency, 31 J. FIN. 1141, 1148 (1976), each find that insiders garnered significantly abnormal returns via their reported purchases and sales of their firm's shares, an observation consistent with insiders deploying confidential corporate information to their personal advantage. Not captured by Jaffe and Finnerty is the extent, if any, that the same insiders share their good fortune by tipping friends and relatives so that the ill-gotten gains are more pervasive than those reaped by the director, officer, or beneficial owner of a reporting company that files $\S 16(\mathrm{a})$ reports.

Furthermore, traders adjust their use of inside information to avoid detection by regulators, such as by not trading close to announcements when such activity might trigger increased scrutiny. Bin Ke, Steven Huddart \& Kathy Petroni, What Insiders Know About Future Earnings and How They Use It: Evidence from Insider Trades, 35(3) J. Асст. \& ECON. 315, 315-16 (2003) (finding that stock sales by insiders increase three to nine quarters prior to announcement of news of declining earnings, but not in the two quarters just before the announcement).

2. See Manish Agarwal \& Harminder Singh, Merger Announcements and Insider Trading Activity in India: An Empirical Investigation, 3 Inv. Mgmt. \& Fin. Innovations 140, 145 (2006).

3. See Arthur J. Keown \& John M. Pinkerton, Merger Announcements and Insider Trading Activity: An Empirical Investigation, 36 J. FIN. 855, 866 (1981) (examining 194 merger announcements); see also Lisa K. Meulbroek, An Empirical Analysis of Illegal Insider Trading, 47 J. FIN. 1661, 1662 (1992). The stock market is not the only venue where the insiders reap the rewards; data confirms that put and call options are astutely used by insiders to reap gains in the pre-takeover period. See Tom Arnold, Gayle Erwin, Lance Nail \& Terry Nixon, Do Option Markets Substitute for Stock Markets? Evidence from Trading on Anticipated Tender Offer Announcements, 15 InT'L Rev. Fin. Analysis 247, 247 (2006); Narayanan Jayaraman, Melissa B. Frye \& Sanjiv Sabherwal, Informed Trading Around Merger Announcements: An Empirical Test Using Transaction Volume and Open Interest in Options Market, 37 FIN. REV. 45, 46 (2001).

4. Keown \& Pinkerton, supra note 3, at 866.

5. See Patrick Augustin, Menachem Brenner \& Marti G. Subrahmanyam, Informed Options Trading Prior to M\&A Announcements: Insider Trading? 27 (Oct. 26, 2015) (working paper) (on file with author).

6. Id. at 2.

7. See Viral V. Acharya \& Timothy C. Johnson, More Insiders, More Insider Trading: Evidence from Private-Equity Buyouts, 98 J. FIN. ECON. 500, 500 (2010). 
Johnson found a correlation between the number of insiders and the likelihood of insider trading on any one deal. ${ }^{8}$ This extends to institutional involvement. ${ }^{9}$ In another study, the same authors report that as the number of banks monitoring a given firm as part of a lending arrangement increases, the more likely there is going to be evidence of trading of credit default swaps on nonpublic information, suggesting those banks are using inside information to hedge against risk. ${ }^{10}$ But, not all the preannouncement market movement can be attributed to insiders and their tippees; there is evidence of abundant price-discovery efforts by "uninformed" traders who mimic the insider's trading, so a certain amount of "piling on" accompanies the illicit trading of those in the know. ${ }^{11}$

If there is a silver lining in the pervasiveness and price impact of insider trading, it is that such insider trading not only drives securities prices in the direction of the post-announcement equilibrium level, but also appears to be related to such price discovery efforts, and may well have the effect of reducing other forms of compensation that insiders and their advisors may have obtained. ${ }^{12}$ Such "positive" byproducts, however, should not be considered in a vacuum. ${ }^{13}$ The merits, if any, of insider trading should be considered in the context of the public policy advanced by circumscribing the use of material nonpublic information. The thesis set forth below is that the facts of SEC v. Texas Gulf Sulphur Co. ${ }^{14}$ (hereinafter "TGS") provide an excellent backdrop to divine a public policy supporting present day insider trading laws. Far more useful than the empty fiduciary rhetoric that now frames ticklish factual inquiries are instrumentalist considerations that are not far below the surface of TGS. ${ }^{15}$

\section{FROM THE CLARITY OF PARITY OF INFORMATION TO THE MIST OF FIDUCIARY DUTY}

The data summarized above reflects the great challenges regulators face in deterring insider trading. The challenges were not present in the facts of $T G S$, which appear quaint by contemporary standards. ${ }^{16}$ This may call for pause in celebrating the decision's half-century life. If the

\section{See id.}

9. See Viral V. Acharya \& Timothy C. Johnson, Insider Trading in Credit Derivatives, 84 J. Fin. ECON. 110, 112 (2007).

10. See id.

11. See Meulbroek, supra note 3, at 1661-62.

12. See M. Todd Henderson, Insider Trading and CEO Pay, 64 VAND. L. REv. 505, 513,542 (2011) (collecting data reflecting that executives who are subject to fewer constraints in trading their company's stock experience reductions in other forms of compensation).

13. See James D. Cox, Insider Trading and Contracting: A Critical Response to the "Chicago School," 1986 Duke L. J. 628, 635, 642 (claims of efficiency associated with insider trading are overstated because insider trading is a slow and clumsy method to impart newsworthy information vis-à-vis a clarion corporate announcement).

14. SEC v. Texas Gulf Sulphur Co., 401 F.2d 833, 843-47 (2d Cir. 1968) (en banc), cert. denied, 394 U.S. 976 (1969).

15. See id.

16. See id. at $843-47$. 
regulation of insider trading appears weak in light of repeated studies of its pervasive presence, what then is the benefit of continuing to champion $T G S$, the primogenitor of our regulatory thrusts? Certainly the uninitiated should question why $T G S$ is pedestalized when so many decisions over the last fifty years provide multiple qualifications to its simple, broad prohibition. This question is further justified in light that there have now been so many Supreme Court decisions refining and sometimes rejecting key features of the decision.

Even though much has intervened in the last half-century, major business organization casebooks continue to include $T G S .{ }^{17}$ For example, in my business organization class, I continue to divide class time fairly and equally between discussing $T G S$ and the tapestry woven by various congressional, SEC, and Supreme Court forays into the realm of insider trading regulation. My preoccupation with $T G S$ is not due to inertia grounded in dog-eared notes, but a natural embrace of the richness of the $T G S$ facts and the issues they presented to the court. TGS's unique facts allowed the court an enduring context to thoughtfully explore a range of technical questions, such as: what constitutes a material fact when the information turns on an outcome that is uncertain to occur; what it means to be "in possession" of proscribed information; what the disclosure obligations of officers and employees are to the board of directors; and what constitutes the public disclosure of inside information. ${ }^{18}$ Indeed, no other case since $T G S$ has similar richness of facts for such pivotal issues to be developed. What truly sets $T G S$ apart is its opacity on the core of the case: why insider trading is proscribed. Its vagueness naturally invites conjecture on how its carefully developed record overcomes that weakness to divine a solid foundation for regulating insider trading.

The most distinguishing aspect of TGS is the sharp contrast its reasoning provides to the later Supreme Court decisions cabining insider trading regulation in the midst of fiduciary duty law. TGS straightforwardly observed:

[The] Rule is based in policy on the justifiable expectation of the securities marketplace that all investors trading on impersonal exchanges have relatively equal access to material information. The essence of the Rule is that anyone who, trading for his own account in the securities of a corporation has "access, directly or indirectly, to information intended to be available only for a corporate purpose and not for the personal benefit of anyone" may not take "advantage of such information knowing it is unavailable to those with whom he is dealing," i.e. [sic] the investing public. Matter of Cady, Roberts \& Co., 40 SEC 907, 912 (1961). Insiders, as directors or management officers are, of course, by this Rule, precluded from so unfairly dealing, but the Rule is also applicable to one possessing the information

17. See, e.g., Roger LeRoy Miller, Business Law Today, The Essentials: Text and Summarized Cases 621-22 (Erin Joyner et al. eds., Cengage Learning 10th ed. 2014).

18. See Texas. Gulf Sulphur, 401 F.2d at 848, 849, 856, 870. 
who may not be strictly termed an "insider". . . .19

From this parity of information perspective, the opinion broadly concludes:

[A]nyone in possession of material inside information must either disclose it to the investing public, or, if he is disabled from disclosing it in order to protect a corporate confidence, or he chooses not to do so, must abstain from trading in or recommending the securities concerned while such inside information remains undisclosed. ${ }^{20}$

The imposition of the disclose-or-abstain rule on "anyone" follows naturally from the court's view that market participants expect corporate insiders will use corporate information for corporate and not personal purposes. ${ }^{21}$

The mystical fiduciary orientation that now guides insider trading regulation began with Chiarella v. United States.22 Justice Powell's opinion in Chiarella stopped further resort to parity of information as the lynchpin for insider trading regulation. ${ }^{23}$ Chiarella holds that the sine qua non for a duty to disclose on anyone's part is the presence of a fiduciary relationship.

[L]iability is premised upon a duty to disclose arising from a relationship of trust and confidence between parties to a transaction. . . . [Chiarella] was not a fiduciary, he was not a person in whom the sellers had placed their trust and confidence. He was, in fact, a complete stranger who dealt with the sellers only through impersonal market transactions. ${ }^{24}$

Thus, Vincent Chiarella, a mere employee of a printer hired by a tender offeror, escaped criminal conviction when he traded in the shares of forthcoming tender offer targets based on the knowledge he purloined through his work with the printer. ${ }^{25}$ Chiarella never explores why the fiduciary relationship is appropriate for the securities laws that were enacted for the express purpose of protecting participants-investors, market intermediaries, and shareholders-in impersonal markets. Indeed, we can easily understand that the enactment of the securities laws, and thereby the imposition of mandatory duties that operate in a variety of contexts, were intended to overcome deficiencies long-recognized in the common law. ${ }^{26}$ For these reasons, importing fiduciary duty analysis from the common law is not a convincing approach to defining obligations under the federal securities laws. At common law, corporate insiders owe no duty to disclose any kind of material information before

\footnotetext{
19. Texas Gulf Sulphur, 401 F.2d at 848 (internal citations omitted).

20. Id.

21. See id.

22. See generally Chiarella v. United States, 445 U.S. 222 (1980).

23. See id. at 248.

24. Id. at $230,232-33$.

25. See id. at 224 .

26. See id. at 233 .
} 
trading. ${ }^{27}$ This neither supports $T G S$ 's holding nor does it justify the limit on $T G S$ 's reach imposed by Chiarella. Aside from such illogic, it would seem inconsistent with the intended public policy of the federal securities laws that were enacted to add disclosure duties where they were absent at common law. ${ }^{28}$ These oversights might well explain why the fiduciary analysis quickly and seriously unraveled in two subsequent Supreme Court decisions.

Chiarella's analysis is at best a triumph of formalism. Had Vincent Chiarella purchased the bidder's shares (believing the acquisition would be viewed as beneficial to the bidder as well as the target), the requisite fiduciary relationship would have existed and his conviction upheld. ${ }^{29}$ Hence, Chiarella's fate turned not on well-grounded policy anchored in the objectives of the securities laws, but instead upon fortuity of which company's shares he purchased. ${ }^{30}$ In so reasoning, Chiarella embraced the artificial distinctions that for decades prevented common law deceit actions from reaching insider trading, such as imposing liability on insiders who purchase shares from existing stockholders, but not when the insider sells shares to outsiders. ${ }^{31}$

Setting aside quibbles naturally surrounding formalism, there remains the larger question that is not addressed by Justice Powell-Why would fiduciary duty law proscribe Chiarella's trading in the bidder's shares more readily than the target's shares? Agents, such as Chiarella's employer, are burdened by a duty not to use information secured through their relationship that would harm or act contrary to the principal's interest. ${ }^{32}$ It is easy to conjecture many ways by which Chiarella's trading poised such harm. Because Chiarella repeatedly traded through the same broker on his advance knowledge of prospective bidder targets, he created a serious risk that the broker, who through surmise did ultimately understand Chiarella's information advantage, could have sold his knowledge of Chiarella's trading to hedge funds. Those hedge funds' advance trading would increase the price of the prospective target shares with the effect of either reducing the bidder's anticipated gains or prompting the bidder to increase its bid to assure a sufficient premium over market was offered for it to succeed. Thus, a focus that a fiduciary threatens the principal only by trading in the principal's shares is at best myopic.

27. See Goodwin v. Agassiz, 186 N.E. 659, 660-61 (1933) (no disclosure duty owed by directors and officers when trading on an impersonal market such as an exchange). Even the earlier "special facts" cases tracing their roots back to the Supreme Court in Strong $v$. Repide, 213 U.S. 419 (1909), addressed only instances where the plaintiff and defendant dealt with one another through a common intermediary and not through the more anonymous trading mechanisms that characterize trades in organized markets.

28. See generally Smaller Reporting Company Regulatory Relief and Simplification, 17 C.F.R. pts. 210, 228, 229, 230, 239, 240, 249, 260, 269 (2017).

29. See Chiarella, 445 U.S. at 233.

30. See id. at 231.

31. See id. at 233-34.

32. See Restatement (Third) of Agency $\S \S 8.01-8.05$ (Аm. Law Inst. 2006). 
In United States v. O'Hagan, ${ }^{33}$ the Supreme Court provided for the protection of the principal's interest by embracing the misappropriation theory of insider trading, while also holding that the fiduciary talisman was not needed under insider trading and tipping prosecuted under the Rule 14e-3. ${ }^{34}$ O'Hagan held that a lawyer who learned the identity of a target of a takeover through the confidential relationship his firm had due to the firm representing the bidder violated Rule $10 \mathrm{~b}-5$ by purchasing call options for the target's shares. ${ }^{35}$ O'Hagan reasoned that O'Hagan procured the confidential information by failing to disclose he would use the information to trade, and through a broad reading of the "in connection with" requirement, the Court deemed O'Hagan's nondisclosure of his intent to trade to be in connection with his subsequent trade. ${ }^{36}$ O'Hagan thus squares the circle behind the fiduciary mist of linking O'Hagan's infidelity to the principal. ${ }^{37}$ Nonetheless, O'Hagan fails to link its analytical gymnastics with any broader policy objective than proscription of misappropriating market-moving information. Its loose construction of the "in connection with" language for the purpose of upholding O'Hagan's conviction overcomes Chiarella's formalism, but does so with reasoning that appears to be a little more than sleight of hand. ${ }^{38}$

O'Hagan is even more elliptical in its analysis of Rule 14e-3. O'Hagan had challenged the government's prosecution under the provision on the ground that the jury was not instructed on the necessity of finding a preexisting fiduciary duty owed by O'Hagan. ${ }^{39}$ The Supreme Court held no fiduciary relationship need exist for such a charge, relying on the broad rule-making authority the SEC enjoys under $\S 14(\mathrm{e})$ to adopt rules that would be a meaningful prophylaxis to fraudulent conduct in connection with tender offers. ${ }^{40}$ Even though O'Hagan deftly and definitively excludes the fiduciary rubric from that provision's reach, it clouds the result by not fully explaining just why the rule-making authority the SEC enjoys under $\S 10(\mathrm{~b})$ is to be understood as less sweeping than that under $\S 14(\mathrm{e}) .{ }^{41}$

The Supreme Court further distorts the fiduciary concept in Dirks $v$. $S E C .^{42}$ Ronald Secrist, after ceasing his employment with Equity Funding, famously tipped Raymond Dirks, informing him that the life insurance policies mutual funds making up most of Equity Funding's assets were "vastly overstated as the result of fraudulent corporate practices." 43

33. United States v. O'Hagan, 521 U.S. 642 (1997).

34. See id. at 634-44. See generally Transactions in Securities on the Basis of Material, Nonpublic Information in the Context of Tender Offers, 17 C.F.R. § 240.14e-3 (2017).

35. O'Hagan, 521 U.S. at 655-56, 661. See generally Employment of Manipulative and Deceptive Devices, 17 C.F.R. § $240.10 b-5$ (2017).

36. See O'Hagan, 521 U.S. at 655-56.

37. See id.

38. See id. at 661.

39. See id. at $700-01$.

40. See id. at 671-76.

41. See id. at $672-73$.

42. Dirks v. SEC, 463 U.S. 646 (1983).

43. Id. at 649 . 
While investigating the accuracy of Secrist's report, Dirks shared the alarming information with several funds, who over time sold $\$ 16$ million in Equity Funding shares. ${ }^{44}$ The gigantic fraud by Equity Funding was ultimately revealed; the SEC reflected its gratitude to Dirks by disciplining him through a letter of censure. ${ }^{45}$ Dirks, believing he was the victim of SEC overreach, pursued his case to the Supreme Court, where Justice Powell once again invoked the fiduciary framework. ${ }^{46}$ The Court held that a tip is proscribed "only when the insider [Secrist] has breached his fiduciary duty to the shareholders by disclosing the information to the tippee and the tippee knows or should know that there has been a breach." 47 Thus, the tippee's ability to trade depends on whether the selective disclosure "constituted a breach of the insider's fiduciary duty." 48 This, the Court stated, is to be judged by the objective criteria of "whether the insider personally will benefit, directly or indirectly, from his disclosure." ${ }^{49}$ Gains identified in Dirks, and affirmed decades later in Salman v. United States, ${ }^{50}$ are pecuniary gains, "reputational benefit that will translate into future earnings," and a "gift of confidential information to a trading relative or friend." 51 The Court proceeds to state that absent a personal gain, there is no breach. ${ }^{52}$

Each of these examples appear well within fiduciary boundaries. But what if the tipping insider gains no benefit by making the selective disclosure other than peace of mind? For example, the lawyer in O'Hagan advising Grand Metropolitan on its secret plans to make a hostile bid for Pillsbury Company could fear that Grand Metropolitan's takeover of the hometown firm would harm Minneapolis. ${ }^{53}$ Certainly there would be a breach of her fiduciary duty to the client if the lawyer tipped Pillsbury of the plan so as to enable Pillsbury to successfully defend itself. This selective disclosure, however, is not within any of the bases Dirks identifies as making the selective disclosure improper. ${ }^{54}$

Buried in Dirks and not referenced in Salman, is what could be the Court's quest for the objective factors it identified that render a tip improper.

44. Id.

45. Id. at $651-52$.

46. See id. at 666 .

47. $I d$. at 660 .

48. Id. at 661 .

49. Id. at 662 .

50. Salman v. United States, 137 S. Ct. 420 (2016) (rejecting defense that Dirks requires the government to establish that the tipper's goal in making the selective disclosure is to garner something of tangible value, like money or property). Salman thus triggered the Second Circuit in United States v. Martoma, 869 F.3d 58 (2d Cir. 2017), to reject its prior requirement that the government must establish the tippee was aware that the tip was made to obtain such a tangible reward and that mere ties of family or friendship alone were not sufficient. See United States v. Newman, 773 F.3d 438 (2d Cir. 2014).

51. Dirks, 463 U.S. at 663-64. The same objective factors were embraced most recently in Salman. See Salman, 137 S. Ct. at 422, 427.

52. Dirks, 463 U.S. at 667.

53. See United States v. O'Hagan, 521 U.S. 642, 647-48, 659.

54. See Dirks, 463 U.S. at 663-64. 
Imposing a duty to disclose or abstain solely because a person knowingly receives material nonpublic information from an insider and trades on it could have an inhibiting influence on the role of market analysts, which the SEC itself recognizes is necessary to the preservation of a healthy market. It is commonplace for analysts to "ferret out and analyze information," ... [citing to reasoning in the SEC's opinion disciplining Dirks] and this often is done by meeting with and questioning corporate officers and others who are insiders. And information that the analysts obtain normally may be the basis for judgments as to the market worth of a corporation's securities. The analyst's judgment in this respect is made available in market letters or otherwise to clients of the firm. It is the nature of this type of information, and indeed of the markets themselves, that such information cannot be made simultaneously available to all of the corporation's stockholders or the public generally. ${ }^{55}$

Dirks, seeking a standard that facilitates the analysts' worthy function of unearthing nonpublic information, inserts objective criteria, premised on gain to the tipper, as the litmus for determining whether a tip is improper. ${ }^{56}$ More broadly, under the empty "fiduciary" rubric, Dirks does much more by acting instrumentally to incent the lawful pursuit of nonpublic information, i.e., by not conferring gain to the tipper.

The full import of Dirks' requirement of objectively observable benefits to the tipper can be understood against the facts of a pre-Dirks decision, SEC v. Bausch \& Lomb, Inc. ${ }^{57}$ Even though Bausch \& Lomb was experiencing rapid growth in revenues after introducing soft contact lenses, rumors circulated within the investment community regarding possible product recalls and overstocking by customers. ${ }^{58}$ There ensued a feeding frenzy by various analysts who focused on the company's chairman, Schuman. ${ }^{59}$ Employers of a few of the most aggressive analysts traded Bausch \& Lomb shares during this period, and the SEC alleged they did so in reliance on wrongful tips by Schuman. ${ }^{60}$ All the charges were ultimately dismissed, many on the grounds that Schuman deftly conformed his replies to analysts to facts already publicly available. ${ }^{61}$ In the sole instance where Schuman selectively disclosed material nonpublic information, he quickly took steps to make the selectively disclosed information publicly available. ${ }^{62}$ Then, in finding that Schuman did not act improperly, the court emphasized that his actions were careless, but did not rise to the level of scienter required for violations of the antifraud provision. ${ }^{63}$

\footnotetext{
55. Id. at $658-59$.

56. See id. at 658-59.

57. SEC v. Bausch \& Lomb, Inc., 420 F. Supp. 1226 (S.D.N.Y. 1976).

58. Id. at $1228-29$.

59. Id. at 1230 .

60. Id. at $1236-37$.

61. Id. at 1236,1243 .

62. Id. at 1244 .

63. Id. at 1237.
} 
This opinion is instructive because its close analysis of the facts documents how intense and persistent financial analysts can be in their trade of "ferreting out" financially significant information. ${ }^{64}$ Although their actions were likely seen by Schuman and other Bausch \& Lomb officers as nettlesome, the facts reflect the profession of the financial journalists and their role in the price discovery process. The case is also prescient of the holding in Dirks by judging any wrongfulness of Schuman's selective disclosure by objective criteria-he moved to correct the gaff by taking steps to make the information publicly available soon after becoming aware of his mistake, and he garnered no financial reward for himself as a result of the tip. ${ }^{65}$

Even though the above reflects that the Supreme Court embraces strong public policy reasons for conditioning proscription of tipping on objective indicia of personal gain, the Court did not examine why a selective disclosure for personal gain should be proscribed. Thus, we see that in the one area-tipping liability-where the Court has provided the most explanation for its holdings, we are still adrift. Overall, the fiduciary principle may have some analytical value in explaining relationships that support a violation in particular instances, but as a matter of explaining why those relationships should justify proscription of trading or tipping, fiduciary law the case law is an empty vessel.

\section{FINDING PURPOSE IN TGS'S FACTS}

$T G S$ 's embrace of a goal that investors enjoy equal access to material information was utopian in its time and lacks even less salience in conceiving today's markets. ${ }^{66}$ Broad claims that securities markets must be "fair" as well as the claims that the insiders' informational advantage are antithetical to fairness, are each out of step with many demonstratively unfair practices that prevail in contemporary capital markets. ${ }^{67}$ Colocation of trading facilities, the ability of a suitor to engage in market purchases before announcing its hostile bid for a target, and the practices whereby some vendors (for a fee) provide some investors with earlier access to market-moving information persist in today's markets. ${ }^{68}$ The prevalence of such practices questions any claim that investors truly believe information is equally accessible. ${ }^{69}$ Nonetheless, not only was such inequality within TGS's facts, but the justification for embracing inequality can also be found in those same facts while, at the same time, justifying the regulation of insider trading.

64. See id. at 1230.

65. See id. at 1243.

66. See Janet Austin, What Exactly is Market Integrity? An Analysis of One of the Core Objectives of Securities Regulation, 8 WM. \& MARy Bus. L. Rev. 215, 237 (2017).

67. See id. at 227, 235-36.

68. See id. at 220-21.

69. See id. at 231. 


\section{A. Protecting the Reward for Initiative}

The first step to locating a basis for regulating insider trading is TGS's finding that the initial core drilling began the process whereby TGS would ultimately announce it had discovered staggering amounts of valuable minerals. ${ }^{70}$ The visual assay of that core drilling, the famous K-55-1, was determined to be material based on the trial testimony of mining reporters, who explained how the defendants engaged in extraordinary trading in TGS shares and options immediately upon learning of the richness of the visual assay. ${ }^{71}$ What the court could have emphasized in its holding was that, without waiting for the formal assay of K-55-1, senior management instructed the on-site drilling crew to withdraw and launched a program that would ultimately lead to TGS engaging in a variety of subterfuges to enable it to secretly purchase vast holdings in the vicinity of K-55-1. ${ }^{72}$ The company's treatment of knowledge of K-55-1 not only supports a holding that it is material, but also points toward a justification for proscribing insider trading.

TGS had no duty to disclose its knowledge of K-55-1 to those from whom it purchased property. ${ }^{73}$ Indeed, its concealment of its identity as the purchaser, while no doubt materially misleading, is not actionable at common law. ${ }^{74}$ TGS, in its purchases of property in Timmins, Ontario, unquestionably failed to disclose information material to selling landowners; it would have been important to each seller to know that the visual assay of initial core drilling portended a large discovery of copper and zinc (and a few days later, after a formal assay, TGS learned that silver was also discovered), and that the actual purchaser was a large multinational mineral firm who concealed its identity behind various strawmen it employed. ${ }^{75}$ Nonetheless, established doctrine compelled no such disclosure to the hapless selling landowners. ${ }^{76}$ Through this common law principle, the law provides a powerful reward that encourages value-increasing behavior with the ultimate objective of putting property to its highest and best use. If the rule were otherwise, TGS would have invested less, if at all, in the global search for minerals that led to the startling discovery in Timmins, Ontario. Disclosure of the content and promise of K-55-1 to existing landholders would surely have driven the costs of purchasing the parcels of land higher. ${ }^{77}$ This is because landholders could be expected to demand their fair share of the expected value of the discovered minerals as well as because TGS was very likely competing with other mining com-

70. SEC v. Texas Gulf Sulphur Co., 401 F.2d 833, 843, 847 (2d Cir. 1968) (en banc), cert. denied, 394 U.S. 976 (1969).

71. Texas Gulf Sulphur, 401 F.2d at 843.

72. Id.

73. See id. at 848; see also Alan M. Weinberger, Forever Young: Texas Gulf Sulphur Rules at Fifty, 45 Sec. Reg. L. J. (Spring 2017) 1, 9-10.

74. See Weinberger, supra note 73, at 9-10.

75. See Tex. Gulf Sulphur, 401 F.2d at 843, 847-48.

76. See Stephen M. Bainbridge, Insider Trading Regulation: The Path Dependent Choice Between Property Rights and Securities Fraud, 52 SMU L. Rev. 1589, 1608 (1999).

77. See Weinberger, supra note 73 , at 5. 
panies for parcels of land. ${ }^{78}$

$T G S$ simultaneously recognizes TGS's right to use its secret knowledge in real estate markets and calls for material nonpublic information to be equally accessible in securities markets. ${ }^{79}$ But, TGS does not develop why securities markets should call for greater protection of investors against informational advantages than are permitted in other markets, such as the real estate market. ${ }^{80}$ Each property owner in Timmins, Ontario, could in theory have punched their own hole in the Earth's mantle to determine whether the family home was more valuable if used as a quarry rather than a bucolic setting with great fishing. A non-disclosure rule accordingly rewards TGS for taking the risks of committing its resources to pursue a strategy that could result in a more valuable use of the property. If in the process of purchasing Timmons acreage, TGS's agents selectively tipped selling landowners that their land contained high quantities of copper, zinc and silver, as seen earlier, that disclosure would clearly breach the agent's duty to TGS. ${ }^{81}$ The agent's tip erodes the advantages of TGS's incentive behavior with consequential harm - the landowner may not sell at all or may demand a higher price. Worse still, a competing bidder may emerge, free riding on TGS's discovery efforts, and would thus be able to bid more for the property, since it would not have any discovery costs to recover. These fears underlie the broad principle that applies, which is that information the agent obtains in connection with the agency is to be used in furtherance of the agency, not against the principal's interest. ${ }^{82}$

The employee defendants in $T G S$ did not reveal to Timmins landowners their secret knowledge of K-55-1. ${ }^{83}$ Nonetheless, their trading and tipping posed the same risks to TGS's ability to exploit its discovery. It is reasonable to fear that trading, certainly as massive as was carried out by the TGS defendants, could have alerted markets and TGS competitors of on-going material, secret developments at the firm. If this surmise is plausible, then much like the result achieved in the law of agency, discussed above, proscription of the agent's threatening conduct would be a reasonable prophylaxis. ${ }^{84}$

\section{B. Necessary Prophylaxis Explanation}

The protection of property interest justification for insider trading developed here sits poorly with the enforcement experience for insider trading. Few private suits for insider trading are maintained; most

78. See Bainbridge, supra note 76, at 1608-09.

79. Weinberger, supra note 73 , at 2.

80. See id.

81. See discussion supra Part I.

82. See Restatement (Third) of Agency $\S \S 8.01-8.05$ (Am. Law Inst. 2006).

83. SEC v. Texas Gulf Sulphur Co., 401 F.2d 833, 843-47 (2d Cir. 1968) (en banc), cert. denied, 394 U.S. 976 (1969)

84. See discussion supra Part I. 
prosecutions are by the SEC or the Department of Justice. ${ }^{85}$ But such centralization of insider trading enforcement flows naturally from the offense. Insider trading is a crime of stealth so that detection entails costly market surveillance procedures. These procedures are maintained by regulatory bodies, as they monitor compliance with a wide range of legislative and administrative directives designed for the protection of investors and the efficient function of capital markets. In this oversight function, identifying insider trading is something of a byproduct of a broader mission of the securities laws, such as assuring that companies make timely release of market-moving information, investor orders are efficiently and fairly executed, and stock prices are free of manipulation.

To be sure, TGS did not lack the resources to prosecute civilly an agent's harmful misuse of its information. One reason for authorizing the state to pursue insider trading, even when the most visible threat is only to the private interests of the owner of the inside information traded on, is the natural advantage the state enjoys in surveilling markets for insider trading. Individual firms are likely unwilling to invest in expensive technology to monitor the individual firm's stock price and volume to detect insider trading and tipping that affects the firm. On the other hand, monitoring across thousands of publicly traded securities by securities regulators enable the fixed oversight costs to be spread so that the detection of misconduct is more efficient.

The protection of private property interest justification can thus be extracted from the facts of TGS. But it is by no means the sole persuasive justification. As seen, the protection of private property approach is anchored in the common law, and public prosecution is justified by concerns for the efficient protection of private interests. Disquiet nonetheless arises from having such a private view of an area that now enjoys a rich history of public concern. When hedge fund officers are prosecuted for trading on tips from insiders, the proceeding is seen not as protecting a particular individual's private interest but rather vindicating the public interest. The government's commitment to detection and prosecution efforts could be justified on such private concerns. Equally disquieting is that if insider trading regulation is premised solely on the protection of property interest of the information's owner, this understanding could easily devolve into a laissez-faire approach. That is, pursuant to the protection of private property approach, the firm that "owns" the material nonpublic information can freely license others to trade on the information. Thus, as Todd Henderson's study of executive pay arrangements found, firms that provide fewer limits on their executives' trading pay lower compensation to those executives; any shortfall in what such executives receive from their firm is garnered by insider trading gains from unsuspecting investors. ${ }^{86}$ This indeed is the fear of such a privatized view

85. See Robert B. Thompson, Insider Trading, Investor Harm, and Executive Compensation, 50 CASE W. L. Rev. 291, 298 (1999).

86. See Henderson, supra note 12. 
of insider trading. One can hardly be prosecuted on a theory of misappropriating if the owner of the information authorizes trading on that information.

Once again, TGS's facts suggest a strong public reason for regulating insider trading. One of the great mysteries of the case is why TGS managers on April twelfth issued a bland, and to some extent discouraging, press release downplaying rumors that the company had made a large mineral discovery. ${ }^{87}$ That release had marginal impact on the stock's price. ${ }^{88}$ Four days later, TGS issued a second press release, touting the discovery and ultimately driving the stock's price upward. ${ }^{89}$

The opinion never explains why such different announcements could be issued in such a short time. The earlier announcement ultimately gave rise to a settlement with investors, who sold their TGS shares in reliance on that announcement. ${ }^{90} T G S$ sets forth the trading history of the various insiders, which reveals that some of the defendants purchased a fair amount of TGS stock in the interval between the two press releases. ${ }^{91}$

Thus, in $T G S$, two of the major defendants traded in the interval between the misleading April twelfth press release and the corrective April sixteenth press release. ${ }^{92}$ To be sure, each had purchased TGS shares before the misleading press release, but essentially doubled-down after the release.$^{93}$ Indeed, the second largest block of shares traded by any of the TGS insiders occurred in the interval between the misleading release and the corrective public release. ${ }^{94}$

Against this record, we can premise an important justification for insider trading: by proscribing insider trading and tipping that yields a personal benefit to the insider, the law removes an incentive that insiders may have to delay the release of inside information. Stated differently, with investors benefitting from the early rather than later release of information, legal rules can better implement that objective by proscribing insiders who delay the release of information to enable them to exploit their secret knowledge of the information by trading on it.

\section{THE PATHFORWARD}

Since the landmark decision in $T G S$, insider trading regulation appears to have functioned well. Calls for regulatory action did arise when the Second Circuit decided United States v. Newman so that the prosecution of remote tippees, such as hedge fund traders, would be seriously hobbled by a demanding requirement that the prosecutor establish the tippee's knowledge that the tipper had received a tangible benefit by the im-

87. See Texas Gulf Sulphur Co., 401 F.2d at 845.

88. Id. at 846 .

89. Id. at $846-47$.

90. See Cannon v. Texas Gulf Sulphur Co., 55 F.R.D. 308, 310-11 (S.D.N.Y. 1972).

91. Texas Gulf Sulphur, 401 F.2d at 847.

92. Id.

93. Id. at 845 .

94. See id. at 847 . 
proper selective disclosure. 95 These fears were swiftly dashed in Salman. ${ }^{96}$ Similar concerns of threatening gaps surrounded Chiarella only to be overcome by the broad interpretation of the "in connection with" element by the O'Hagan court. ${ }^{97}$ Nonetheless, the puzzle continues: Why do we deploy non-trivial levels of public resources to detect and prosecute insider trading and tipping? While it is sweeping in its own justification for proscribing insider trading, the unparalleled rich facts of $T G S$ also provide a useful background for identifying a few reasons why the law is not only just, but also contemporary in its content.

95. See United States v. Newman, 773 F.3d 438, 442 (2d Cir. 2014).

96. See generally Salman v. United States, 137 S. Ct. 420 (2016).

97. See generally Chiarella v. United States, 445 U.S. 222 (1980); United States v. O’Hagan, 521 U.S. 642 (1997). 